\title{
Estimation and Modeling of Shoreline Changes by the year 1970-2100 between Portonova to Mallipattinam coast using Remote Sensing and GIS
}

\author{
N. Muthukrishnan \\ Department of Earth sciences \\ Tamil University, \\ Thanjavur, TamilNadu, India
}

\author{
R. Mahesh \\ Department of Earth sciences \\ Tamil University, \\ Thanjavur, TamilNadu, India
}

\author{
SK Chaturvedi \\ Department of Civil Engg., \\ SASTRA University \\ Thanjavur, TamilNadu, India
}

\begin{abstract}
Changes in shoreline configurations accelerated due to global warming are world wide concern. Such changes not only affect the flora and fauna of those regions but also the livelihood of the coastal population. In the context, the $7517 \mathrm{~km}$ long coastline of Indian coast behaves differently in different regions. Therefore, in order to assess the shoreline changes taking place in particular coastal regions and predicting the long-term changes in shoreline, there is an urgent need to monitor shoreline changes in different sector of Indian coast. The data generated through such can be very much helpful in taking the policy decision in establishing the various coast facilities in those regions. Shoreline Oscillation map of Bay of Bengal and Palk Strait area on 1:50,000 scale was prepared. In view of the above 1970 Topographic Sheets of Survey of India (SOI) and the National Remote Sensing Agency (NRSA), Hyderabad, India, Landsat TM 5, IRS P6 Imagery of the year 2000, 2008, IRS LISS - III P6 Feb 2005, April 2006, March 2008 Satellite Imageries and Modeling 2100 are utilized to study a 200 kilometer long coastline of central Tamil Nadu Coast between Portonova and Mallipattinam to understand the shoreline changes taken place within a time span of 38 years.

Comparative Shoreline Oscillation map reveal high erosional sedimentation ratio to the extent 73.24 in the sector of Thirumullaivasal to Topputurai during 1970 to 2000 . Based on this study it can be concluded that remote sensing technique will be useful in long term qualitative monitoring of shoreline oscillations. Further the remote sensing study has a good agreement with the physical and observation of shoreline oscillation. The coastal stretch at Portonova, Kodiyampalaiyam, Kameswaram, Naluvedapathi, Periyaguttagai, Muttupet, Mallipattinam were in accretion and quite suitable for tourism like activities where as Killai, Thirumullaivasal, Poompuhar, Tharangambadi, Karaikkal, Nagore, Nagapattinam, Velanganni, Kodiyakkarai, and Atirampattinam and shorelines were in erosion and require attention from coastal authorities. The difference of rate of erosion/ accretion between the remote sensing study and physical observation was due to the coarser resolution of satellite images.

The research deals in detail the sector wise shoreline variation along the $200 \mathrm{~km}$ long coastline of central TamilNadu. This study future emphasizes the need to extend similar studies along the other parts of the Indian Coast.
\end{abstract}

Keywords: Shoreline changes, East coast of India, Sea level variation, TamilNadu coast

\section{INTRODUCTION}

Any changes in sea floor may be the result of sea-level variation or to a change in the elevation of land surface. Changes in absolute water-surface levels are worldwide due to the interconnectivity of the oceans and are termed eustatic changes. Changes in the absolute level of the land are localized. They may be due to tectonic adjustments or due to adjustments caused by their distribution of weight on the land surface. As and when sedimentation or ice build-up occurs, such changes are known as isostatic. A rise in the sea level or down warping of land would involve the opposite movements of sea and land. Synonymous with positive and negative changes are the forms of sea-level transgression and regression, although in many cases these terms also refer to the horizontal movement of the shoreline associated with vertical changes of sea level. Indian shore has experienced submergence and emergence due to global as well as local oscillations of the sea level by multivariate tectonic, fluvial and marine geomorphic processes. The repeated emergence and submergence of coast have been instrumental in shaping the morphological expressions of the continental shelves in general and shoreline in particular (Jayaprakash et al. 2002) proved that the coast is going on emerging by tectonic movement. There is a remarkable difference in the extent of continental shelf of the east coast of India when compared to west coast of India. The shelf on the west coast is broad with thin layer of sediment, while the eastern shelf is narrow with thick layer of sediment (Agarwal 1990). The main objective of the research is to generate the pattern of erosion versus accretion along the coast between Portonova and Mallipattinam over period of time (1970, 2008 and Modeling 2100) and preparation of Shoreline Oscillation maps using multi band satellite data and topographic Sheets data.

An idealized definition of shoreline is that it coincides with the physical interface of land and water. Despite its apparent simplicity, this definition is in practice a challenge to apply. In reality, the shoreline position changes continually through time, because of cross-shore and alongshore sediment movement in the littoral zone and especially because of the dynamic nature of water levels at the coastal boundary (e.g., waves, tides, groundwater, storm surge, setup, run up, etc.). Sandy beaches are common along many of the world's coastlines, yet our understanding of the behavior of beach and nearshore sediment systems on scales of years to decades remains limited. Movement of sediment by waves and currents is both complex and difficult to measure 1970, 2000 and 2008 .

Coastal erosion is a source of widespread concern because of threats to abutting private lands and loss of beach resources. Estimates of beach loss related to shoreline armoring on chronically eroding lands. 


\section{STUDY AREA}

The Cauvery delta shoreline (Central east coast of Tamilnadu, India) (Fig 1), Bay of Bengal, extending between Portonova and Naluvedapati $11^{\circ} 30^{\prime} 32.162^{\prime \prime} \mathrm{N}$ latitudes to $10^{\circ} 30^{\prime} 22.619^{\prime \prime}$ $\mathrm{N}$ and $79^{\circ} 44^{\prime} 38.427^{\prime \prime} \mathrm{E}$ to $79^{\circ} 53^{\prime} 15.836^{\prime \prime}$ E longitudes Naluvedapati and Mallipattinam10 $30^{\circ} 22.619^{\prime \prime} \mathrm{N}$ latitudes to $10^{\circ} 14^{\prime} 46.355^{\prime \prime} \mathrm{N}$ and $79^{\circ} 53^{\prime} 15.836^{\prime \prime} \mathrm{E}$ to $79^{\circ} 14^{\prime} 39.816^{\prime \prime} \mathrm{E}$ longitudes to a length of about $200 \mathrm{~km}$. This area is endowed with a combination of ecosystems including mangroves, sea grass, seaweeds and corals reefs (Ramanujam and Mukesh 1998). Different types of land features formations have also been observed. The coast of Bay of Bengal is mostly underling by Quaternary to Recent formation (Meijerink 1971). One port near Periapattinam had submerged under sea due progradation found in this area (Loveson \& Rajamanickam 1988). The west of this coastal area is bound by heavy delta formations underlined by metamorphic rocks of Pre Cambrian. Being a gradient coast it has developed well fabricated network of deltas, backwater, creeks, protruding deltas, estuaries, back swamps and coral reef etc. The morphogenic disturbances of coral reefs observed at Gulf of Mannar (Jayprakash et al 2002). Anthropogenic disturbances on coral reefs are quit common (Grigg \& Dollar 1990) but by using GIS technology Thanickachalam \& Ramachandran (2002) found that the coral reefs of Mannar were severely suffered by means of shoreline oscillation. Morphological variations in the islands were noticed in these areas (Ramanujam et al 1995). and also entire coastal areas of India (Anjali Bahuguna and Nayak 1994).

Generally, the coastal physiography of the regions around Portonova, Chidambaram and Kodiyakkarai is found to be of moderately undulated in and around the concave swaps (Fig 2). In between such swaps and the shoreline, an undulated plain comprised mainly of alluvium, is noticed. Tidal mudflats are associated with swamps and salt pans. The Coastline between Portonova and kodiayakkarai shows a vast stretch of sandy tract with sand dunes mostly of undulating nature. There are also back water swamps especially near the village killai, Pichavaram and at the mouths of Coleroon river. The terrain is nearly level to very gently sloping one. The gradient is $0-3^{\circ}$, that too, only seawards. The western limit of the coastal belt is the Cauvery delta.

\section{MATERIALS AND METHODS}

Nayak 1991 and SAC 1991 Manual for mapping of coastal wetlands / Landforms and shorelone changes using satellite data were utilized to delineate the features of coastline. Over all coastal geomorphology of India has been published by Ahmed (1972) presents the over all ideas about the features present before 1971. Sea level variation-through bathymetric data (Agarwal 1990) and coastal erosion and accretion (Kalianasundaram et al 1991) were also observed in the imageries. The coastal dynamic maps of east coast of India prepared by Gurugnanam et al 2000 and coastal zone management in India given by Nayak, S.R (2002) gave a vast idea about the oscillation of shoreline of east coast of India.

Survey of India Topographic Sheets (SOI-1970) and Global Position System (GPS) were used in this study. Shoreline Oscillation map of study area on 1: 50,000 scale was prepared manually using 1970 Topographic Sheets. The prepared Shoreline oscillation map was digitized by using ARC-INFO (Arc Map) and a digital Shoreline Oscillation model was prepared using (ArcGIS \& ENVI 4.7) software. March 2008 Satellite Imagery was used and Global Position System was also used to locate the Ground Control Points (GCP). The distance in meters were measured at a particular location with reference to Topographic Sheets and Satellite Imagery shore lines (1970, 2000 \& 2008).

Survey of India toposheet for the year 1970 was used as base map and Landsat TM 5 2000,IRS LISS III P6 image (2005, 2006, 2007 and 2008), were used for delineation of coastline during respective years. The satellite data received from NRSC Hyderabad with radiometric corrections were geometrically corrected using ENVI 4.7, ArcGIS 9.2 software verified with ground truth. Then the shorelines had been digitized for further analysis.

The exact locations of these points were observed and respective latitude and longitude were recorded using Sokkia Totalstation Survey, Dump Level Survey, Global Positioning System (GPS).

Then the coastline was monitored from this Different Satellite Imageries. The average coastline changes were computed in year-wise during 1970, 2005, 2006 and 2008 and modeling 2100 .

\section{RESULT AND DISCUSSION}

\subsection{Changes in Shoreline Between Portonova and Mallipattinam}

Geocoded FCC of IRS LISS - III P6 (Landsat TM 5 2000), 2005, 2006 and 2008 satellite data on 1:50,000 scale belonging to low tide period and Survey of India Topographic map (SOI 1970) on 1: 50000 scale were used to prepare shore line change map. The low tide line (as shore line) from SOI topographical sheet and satellite image were extracted and mapped on 1: 50,000 scale by visual techniques. After identification and delineation, coastal villages, some monuments, lighthouse etc were selected as sample points on SOI topographic sheet for ground truth checking. During the time of ground truth study the entire coast was checked with local people and some necessary corrections were carried out on primary shoreline map. The georeferenced multi date shoreline maps were carefully digitized in ENVI 4.7 ARC/INFO 9.2 and were overlaid using TIC coordinates of the study area. Digitized maps were edited and labels assigned to the polygons. Finally a temporal shoreline change map was generated using intercept operation of ENVI 4.7 ARC/INFO 9.2 and summary statistic was generated for erosion and accretion areas. The changes were estimated for a period of 38 years between 1970 and modeling 2100 .

\subsection{Land use/land cover changes}

The major land use/land cover change has occurred in the following classes:

The sandy beaches are extensively developed along the entire coast of Portonova area. Naluvedapatti, Periyaguttagai is covered by long and extensive sandy beach. Beach ridges are moderately undulating terrain features of marine depositional type, formed during pliestocene to recent age, in the plains of the Kodiyampalaiyam, Kameswaram area. They are low, essentially continuous beach or beach dune materials (sand, gravel and shingle) heaped up by the action of wave and currents on the backshore of a beach beyond the present limit of storm waves or the reach of ordinary tides, and occurring as a single or as one of a series of approximately parallel deposits

1. Sandy, mangroves, Builtup land area has reduced in Killai, Pillumedu

2. Beaches, Beach Ridged Plains, Dunes Vegetations, Cropland, Builtup land area has reduced in Thirumullaivasal, Poompuhar, Tharangambadi

3. Beaches, Beach Ridged Plains, Dunes Vegetations, Paleolagoonal Plains, Mudflats, Point bars, Alluvial Plains, 
Builtup land area has reduced in Karaikkal, Nagore, Nagapattinam,

4. Beaches, Beach Ridged Plains, Dunes Vegetations area has reduced in Velanganni, Naluvedapatti

5. Beaches, Beach Ridged Plains, Dunes Vegetations, Cropland, Mudflats, Salt swamp, Creek, mangroves area has reduced in Kodiyakkarai, Muthupet, Atirampattinam and Mallipattinam. The difference of rate of erosion / accretion between the remote sensing study and physical observation was due to the coarser resolution of satellite images.

\section{CONCLUSION}

The coastal processes in Portonova and Mallipattinam coastal area, the shoreline change, wave action, bathymetry and coastal geomorphology were analysed using Remote Sensing and GIS tools. The erosion and accretion observed at Portonova and Mallipattinam using temporal satellite imageries show that the shoreline dynamics is natural. Coastal processes play a major role in shaping the coastal configuration of this area. The integrative approach using Remote Sensing and GIS tools clearly illustrates both the cause and reasons for the shoreline change. The results of this study will be more useful for shoreline management.

Based on this study, it can be concluded that remote sensing technique will be useful in long term qualitative monitoring of shoreline oscillations. The coastal stretch at Portonova, Kodiyampalaiyam, Kameswaram, Naluvedapatti, Periyaguttagai, Muttupet, Mallipattinam were in accretion and quite suitable for tourism like activities where as Killai, Thirumullaivasal, Poompuhar, Tharangambadi, Karaikkal, Nagore, Nagapattinam, Velanganni, Kodiyakkarai and Atirampattinam and shorelines were in erosion and require attention from coastal authorities.

\section{ACKNOWLEDGMENTS}

Author sincerely acknowledges DST for providing financial assistance in the sea level variation project. He also thanks to the co-author who provide valuable guidance through his wonderful experience in the applied geology field. He thanks the Research Assistant in the project and also acknowledged the SASTRA University for providing necessary infrastructure facilities for the research. The author acknowledges the co-workers of the same project R.Sivasamandy and Mr.R.VijayAnand.

\section{REFERENCES}

[1] Agarwal J.M. (1990), 'Sea level variation-through bathymetric data example: Azhikkal on west coast of India', In: Sea Level Variation and its Impact on Coastal Environment, (ed) Rajamanickam G.V, Tamil University, Thanjavur, pp.1-5.

[2] Ahmad, E., 1972. Coastal geomorphology of India. Orient Longman, New Delhi, $222 \mathrm{p}$.

[3] Anjali Bahuguna, and Nayak, S.R., (1994). Coral mapping of India. In: Scientific Note SAC/RAS/RASG/DOD-COS/SN/07/94), $\quad$ Space Application Center, Ahmedabad, India.
[4] Grigg, R.W. and Dollar, S.J., (1990). Natural and anthropogenic disturbance on coral reefs. Ecosystem of the world, Elsevier Science Publishing, New York, pp.439-452.

[5] Gurugnanam B, Gokulakrishnan R, Ramkumar T and Manoharan K (2000) Coastal Zone Dynamics of the central part of east coast, Tamilnadu- A case studythrough integrated remote sensing. Marine Remote Sensing Applications (Eds: Ramachandran S), pp 235 249.

[6] Jayprakash C, Maran N, Jayakumar R and Kumaran K. (2002), ' Imprints of sea evel oscillation in the continental shelf of Gulf of Mannar', Newsletter, Geological Survey of India, Vol.XVI, pp.8-10.

[7] Kaliasundaram G, Govindasamy S and Ganesan R (1991) Coastal erosions and accretions. Coastal zone management (Tamilnadu State, India) (Eds: Natarajan.

[8] Loveson V.J. and Rajamanickam G.V. (1988a), 'Progradation as evidenced around as evidenced around a submerged ancient port, Periapatnam, Tamilnadu, India', International Journal of Land.Sys.Eclo.Studies, Vol.12, pp.94-98.

[9] Meijerink AMG (1971) Reconnaissance survey of the Quaternary Geology of the Cauvery delta. J Geological Society of India 12: 113-124 .

[10] Nayak, S.R., (1991). Manul for mapping of coastal wetlands/landforms and shoreline changes using satellite data. Technical Note: IRS-UP/SAC/MCE/TN/32/91, Space Application Center, Ahmedabad, India.

[11] Nayak, S.R., (2002). Application of remote sensing to coastal zone management in India. Paper presented in ISPRS Technical Commission VII Symposium on Remote Sensing and Environment Monitoring and ISRS Annual Convension held at Hyderabad, India.

[12] Ramanujam, N. and Mukesh, M.V., (1998). Geomorphology of Tuticorin Group of Island. In: Biodiversity of Gulf of Mannar Marine Biosphere Reserve. (Eds.: M. Rajeswari, K. Anand, Dorairaj and A. Parida). M.S. Swaminathan Research Foundation, Chennai. pp.32-37.

[13] Ramanujam, N., Mukesh, M.V., Sabeen, H.M. and Preeja, N.B., (1995). Morphological variation in some islands in the Gulf of Mannar. Journal of Geogical Survey of India, Vol.45, pp.703-708.

[14] SAC, (1991). Manual for mapping coastal wetlands / landform and shoreline changes using satellite data. Space Application Center, Ahmedabad, India, No: IRSUP/SAC/MCE/TN/32/91, 63p.

[15] Thanikachalam, M.and Ramachandran, S., (2003). Shoreline changes along the coast of Gulf of Mannar and its Influence on Coral Reefs: A Remote Sensing and GIS Approach Journal of the Indian Society of Remote Sensing, Vol.31, No.3, 2003.

Table 1. Shoreline Changes Observed at Portonova and Mallipattinam 
International Journal of Science and Engineering Applications (IJSEA)

Volume 2 Issue 1, 2013, ISSN - 2319-7560 (online)

\begin{tabular}{|c|c|c|c|}
\hline $1970-2000$ & Erosion & Deposition & Ratio E/D \\
\hline Portonova to Tirumullaivasal & 0.459359 & 3.533769 & $1: 8$ \\
\hline Tirumullaivasal to Karaikal & 3.638784 & 0.022915 & 1:0 \\
\hline Karaikal to Velanganni & 2.713319 & 0.136106 & $1: 0$ \\
\hline Velanganni to Topputturai & 3.208456 & 0.078283 & $1: 0$ \\
\hline Topputturai to Kodiyakkarai & 0.174301 & 0.495079 & $1: 3$ \\
\hline Kodiyakkarai to Muttupet & 5.975625 & 5.66344 & $1: 1$ \\
\hline Muttupet to Mallipattinam & 3.819934 & 0.632900 & $1: 0$ \\
\hline Overall & 19.98978 & 10.56249 & $1: 1$ \\
\hline \multicolumn{4}{|l|}{$1970-2008$} \\
\hline Portonova to Tirumullaivasal & 1.144509 & 3.244258 & $1: 0$ \\
\hline Tirumullaivasal to Karaikal & 1.760481 & 0.113573 & $1: 16$ \\
\hline Karaikal to Velanganni & 1.720385 & 0.182227 & $1: 9$ \\
\hline Velanganni to Topputturai & 1.565419 & 0.614851 & $1: 3$ \\
\hline Topputturai to Kodiyakkarai & 4.041669 & 0.230403 & $1: 18$ \\
\hline Kodiyakkarai to Muttupet & 1.104402 & 9.624153 & $1: 0$ \\
\hline Muttupet to Mallipattinam & 1.057505 & 1.438159 & $1: 1$ \\
\hline Overall & 12.39437 & 15.44762 & $1: 1$ \\
\hline \multicolumn{4}{|l|}{$2000-2008$} \\
\hline Portonova to Tirumullaivasal & 1 & 1 & $1: 1$ \\
\hline Tirumullaivasal to Karaikal & 0.076119 & 1.703509 & $1: 0$ \\
\hline Karaikal to Velanganni & 0.136434 & 0.996138 & $1: 0$ \\
\hline Velanganni to Topputturai & 0.167031 & 2.614992 & $1: 0$ \\
\hline Topputturai to Kodiyakkarai & 3.947309 & 0.117502 & $1: 34$ \\
\hline Kodiyakkarai to Muttupet & 0 & 1.199296 & $1: 0$ \\
\hline Muttupet to Mallipattinam & 0.244695 & 10.05343 & $1: 0$ \\
\hline Overall & 5.571589 & 17.68487 & $1: 0$ \\
\hline \multicolumn{4}{|l|}{$2008-2100$} \\
\hline Portonova to Tirumullaivasal & 2.63884 & 8.165299 & $1: 0$ \\
\hline Tirumullaivasal to Karaikal & 4.131833 & 0.754894 & $1: 5$ \\
\hline Karaikal to Velanganni & 7.144319 & 0.168238 & $1: 42$ \\
\hline Velanganni to Topputturai & 4.193459 & 2.180861 & $1: 2$ \\
\hline Topputturai to Kodiyakkarai & 15.75625 & 3.266962 & $1: 5$ \\
\hline Kodiyakkarai to Muttupet & 0.700251 & 9.101234 & $1: 0$ \\
\hline Muttupet to Mallipattinam & 3.206589 & 7.213719 & $1: 0$ \\
\hline Overall & 37.77154 & 30.85121 & $1: 1$ \\
\hline
\end{tabular}

Table 2 Average Shoreline Changes Observed at Portonova and Mallipattinam Coast during 1970, 2000, 2008 from Satellite Imageries and proposed line at 2100

1970-2008

2008-2100

1970-2000 1970-2000 1970-2008 Deposition 2000-2008 Deposition 2008-2100 Deposition

Erosion in Sq Deposition in Erosion in in $\mathrm{Sq} \mathrm{Km}$ Erosion in in $\mathrm{Sq} \mathrm{Km}$ Erosion in in $\mathrm{Sq} \mathrm{Km}$

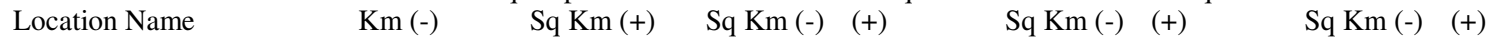

$\begin{array}{lllllllll}\text { Portonova to Tirumullaivasal } & -0.45935906 & 3.53376866 & -1.144509 & 3.244258 & -1.448667 & 0.828352 & -2.63884 & 8.165299\end{array}$

$\begin{array}{llllllllll}\text { Tirumullaivasal to Karaikal } & -3.63878389 & 0.022914884 & -1.760481 & 0.113573 & -0.076119 & 1.703509 & -4.131833 & 0.754894\end{array}$

$\begin{array}{llllllllll}\text { Karaikal to Velanganni } & -2.71331889 & 0.136106147 & -1.720385 & 0.182227 & -0.136434 & 0.996138 & -7.144319 & 0.168238\end{array}$

$\begin{array}{lllllllll}\text { Velanganni to Topputturai } & -3.20845582 & 0.078283102 & -1.565419 & 0.614851 & -0.167031 & 2.614992 & -4.193459 & 2.180861\end{array}$

$\begin{array}{lllllllll}\text { Topputturai to Kodiyakkarai } & -0.1743012 & 0.495079108 & -4.041669 & 0.230403 & -3.947309 & 0.117502 & -15.75625 & 3.266962\end{array}$

$\begin{array}{lllllllll}\text { Kodiyakkarai to Muttupet } \quad-5.97562469 & 5.663440399 & -4.041669 & 0.230403 & 0 & 1.199296 & -0.700251 & 9.101234\end{array}$

$\begin{array}{lllllllll}\text { Muttupet to Mallipattinam } & -3.81993436 & 0.632900155 & -1.057505 & 1.438159 & -0.244695 & 10.05343 & -3.206589 & 7.213719\end{array}$

Overall

$-19.9897779 \quad 10.56249246-15.33164$

$\begin{array}{llll}6.053874 & -6.020255 & 17.51322 & -37.77154\end{array}$

30.85121 
International Journal of Science and Engineering Applications (IJSEA)

Volume 2 Issue 1, 2013, ISSN - 2319-7560 (online)

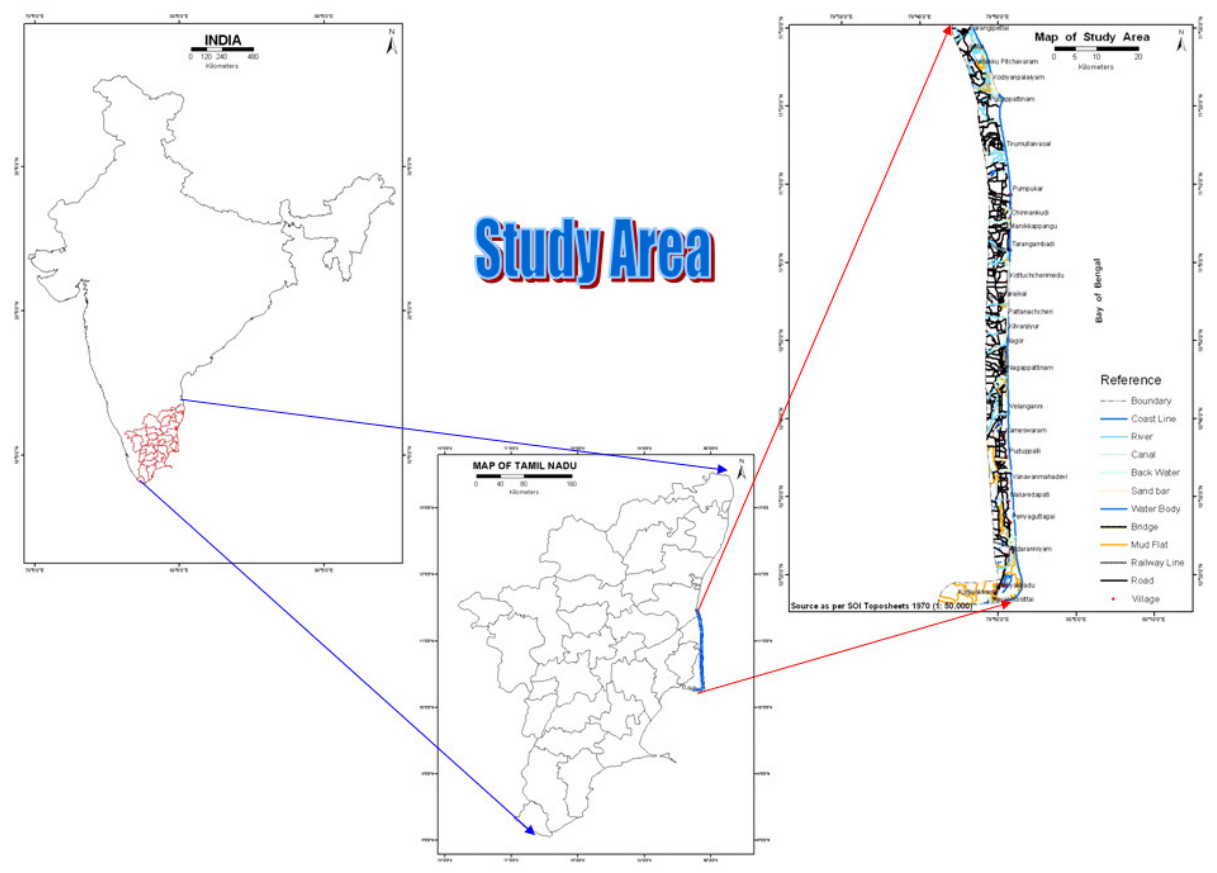

Fig - 1 Study Area

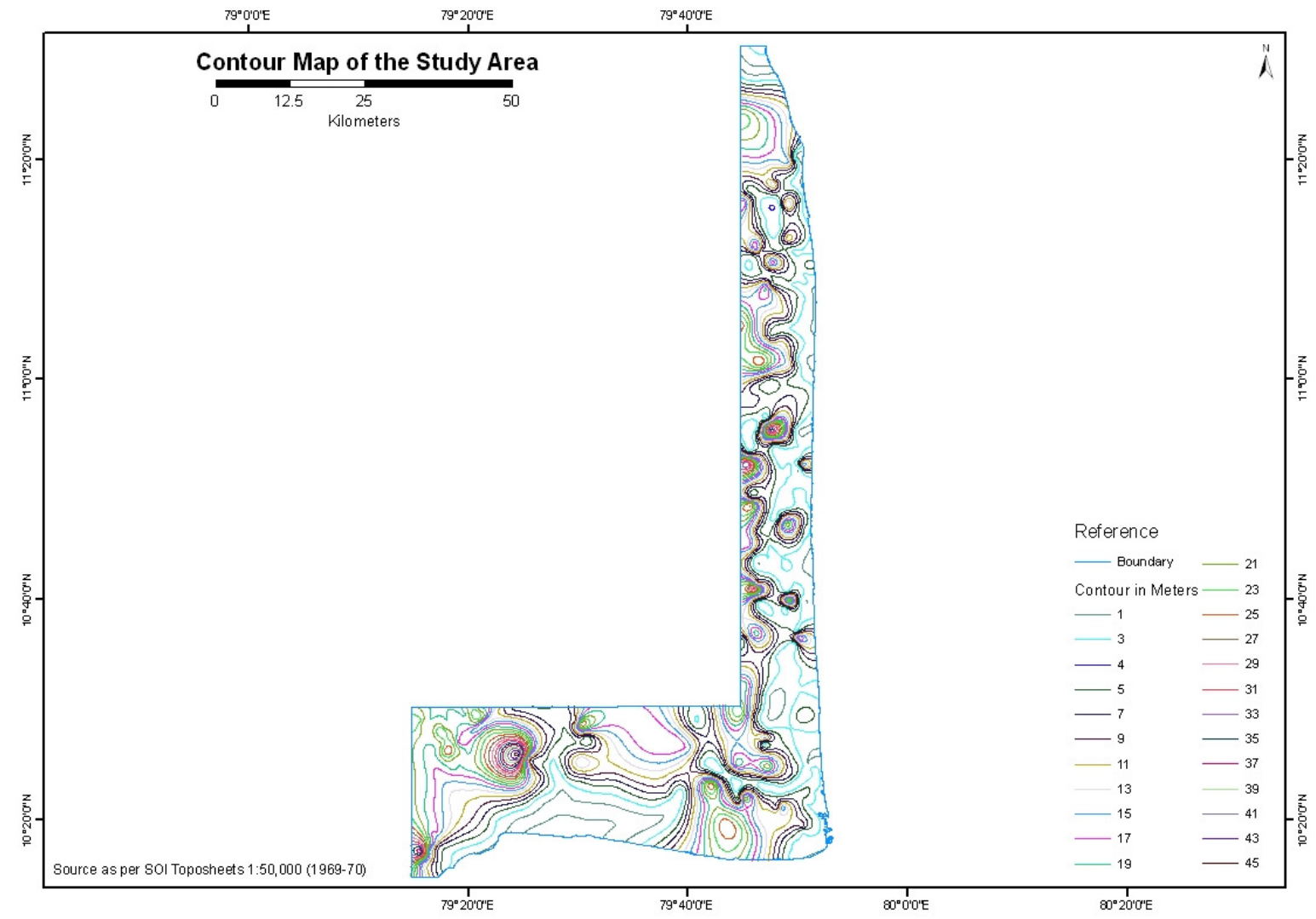

Fig - 2 Contour Map of study area 
International Journal of Science and Engineering Applications (IJSEA)

Volume 2 Issue 1, 2013, ISSN - 2319-7560 (online)

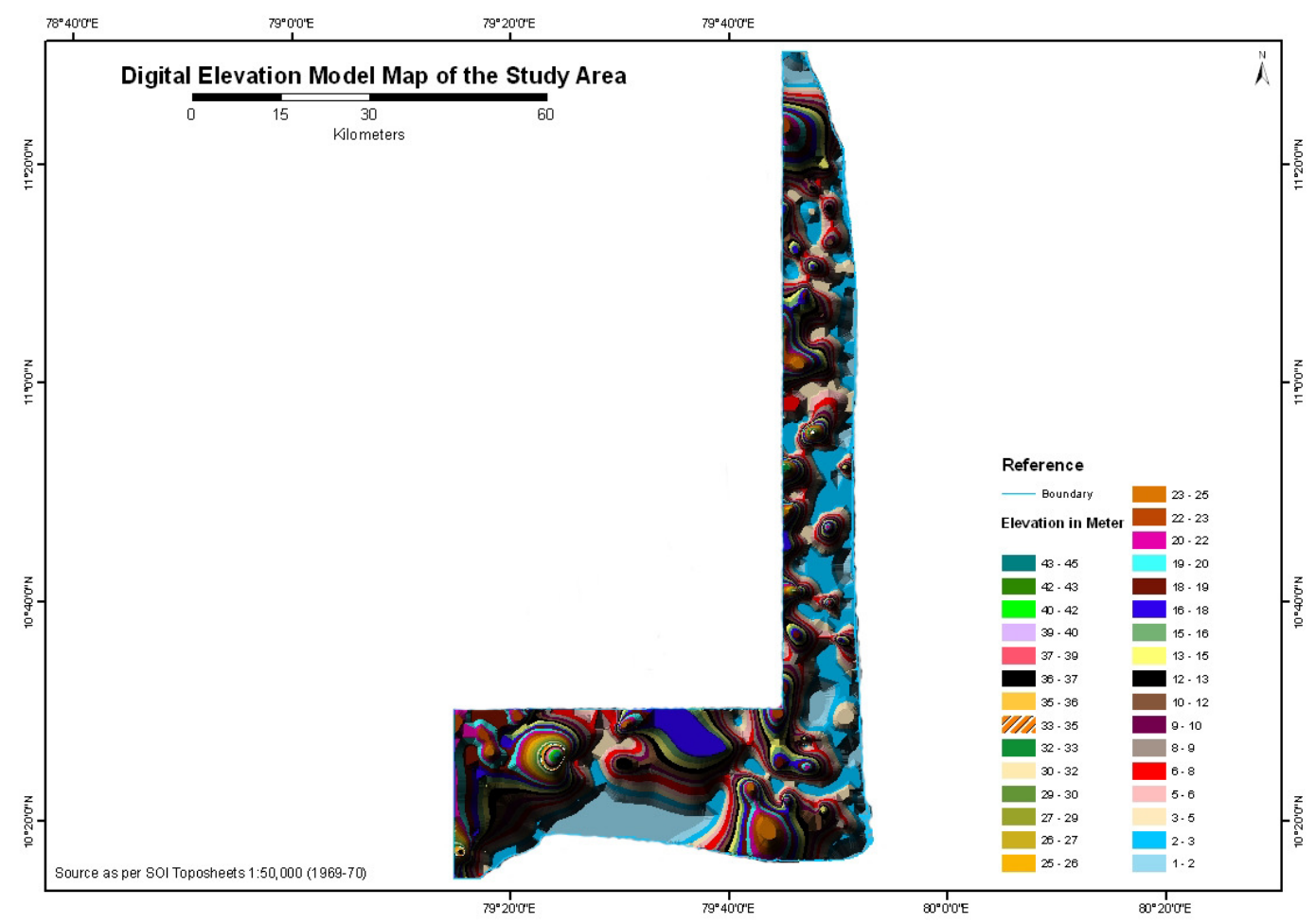

Fig - 3 Contour Map of study area

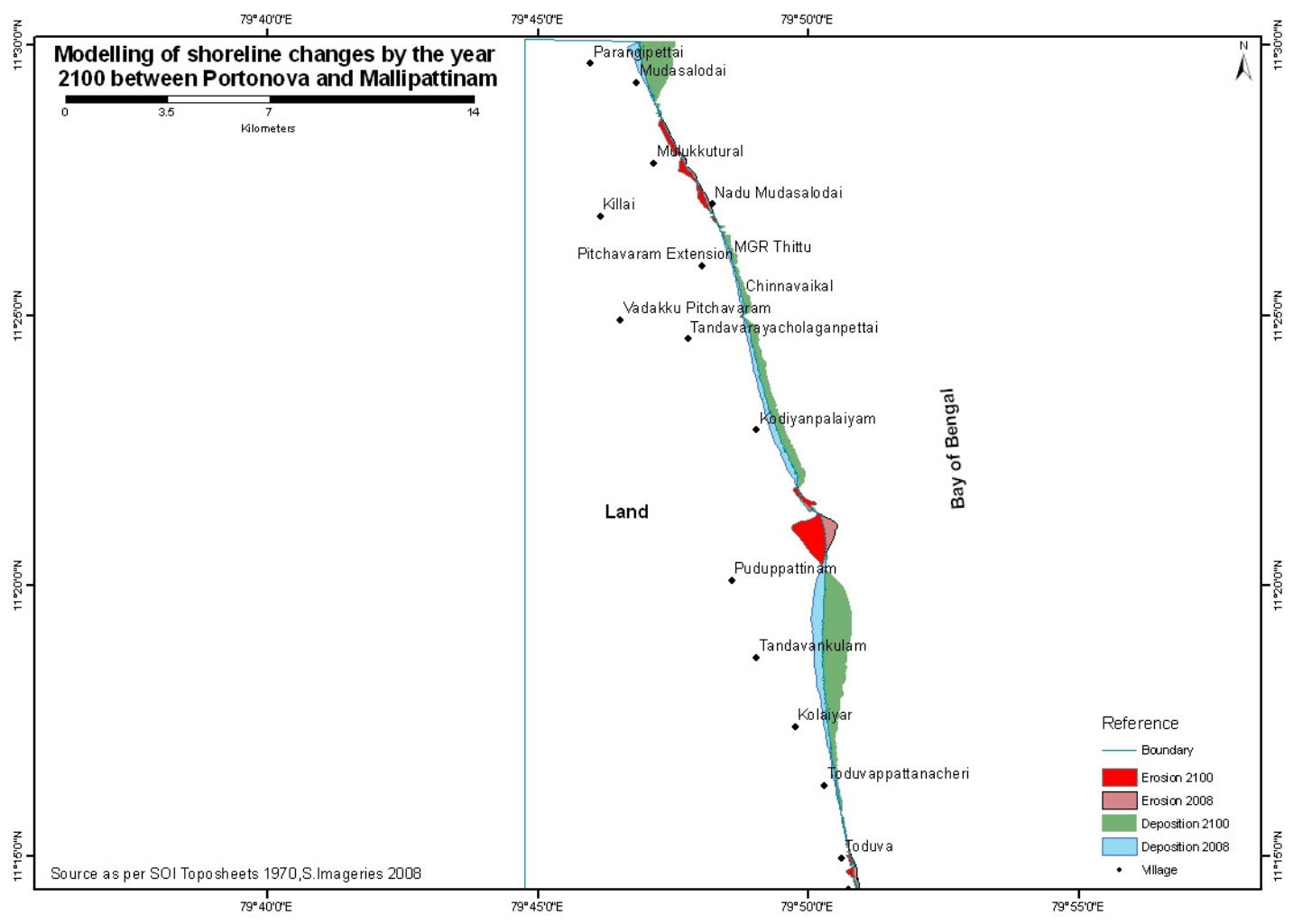

Fig - 4 Portonova to Toduvai 
International Journal of Science and Engineering Applications (IJSEA)

Volume 2 Issue 1, 2013, ISSN - 2319-7560 (online)

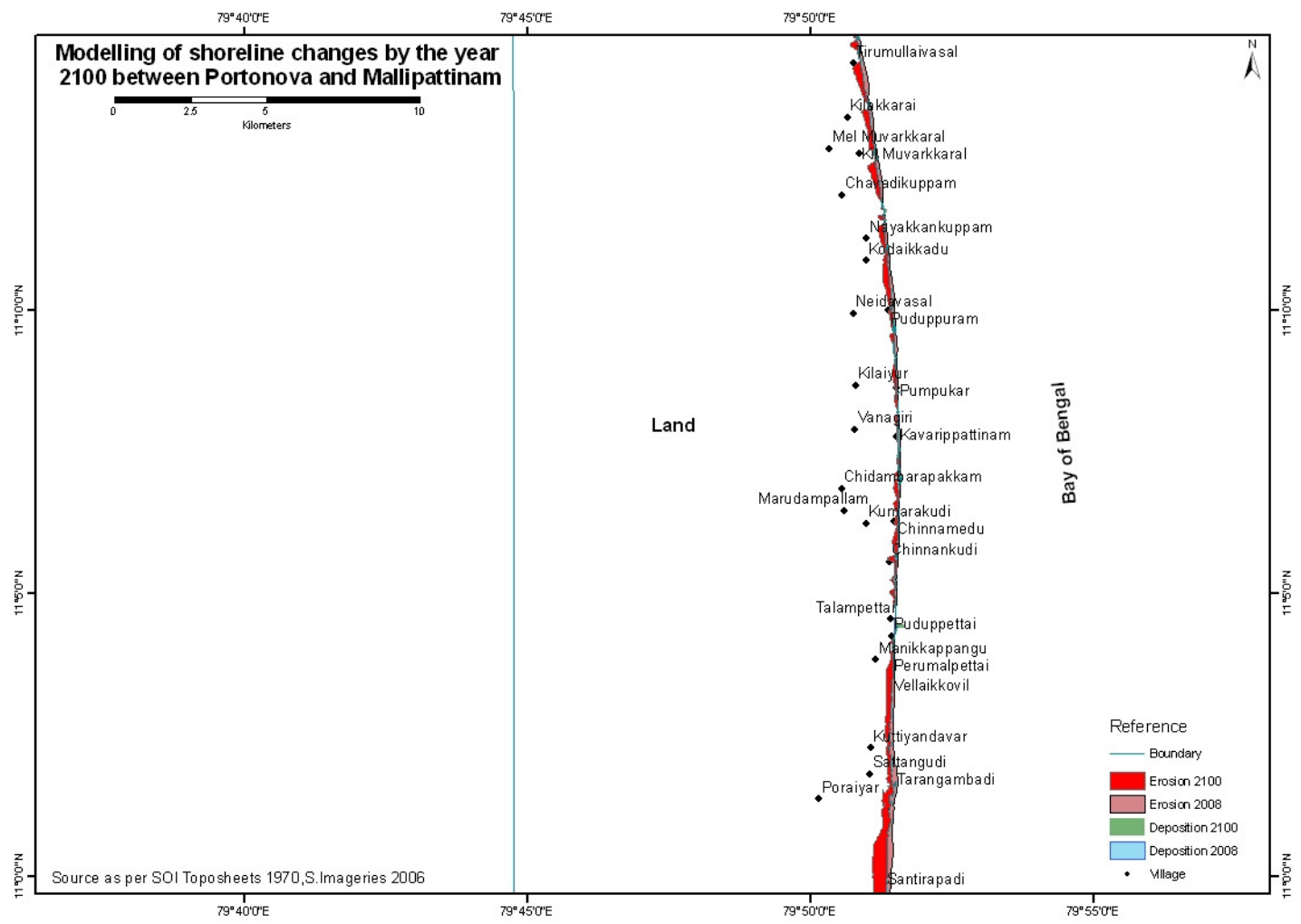

Fig - 5 Thirumullaivasal to Chandrapadi

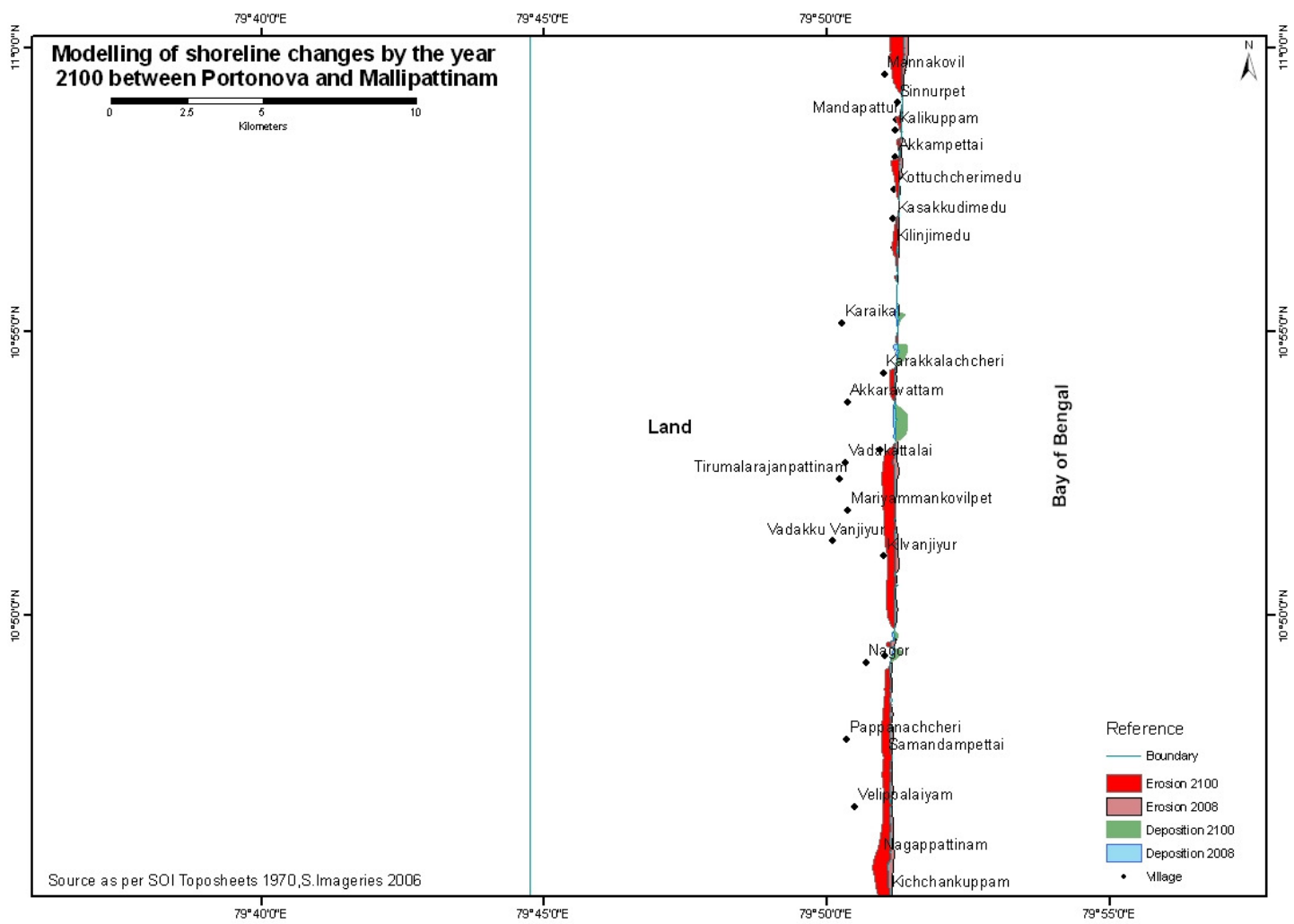

Fig -6 Manakovil Nagapattinam 
International Journal of Science and Engineering Applications (IJSEA)

Volume 2 Issue 1, 2013, ISSN - 2319-7560 (online)

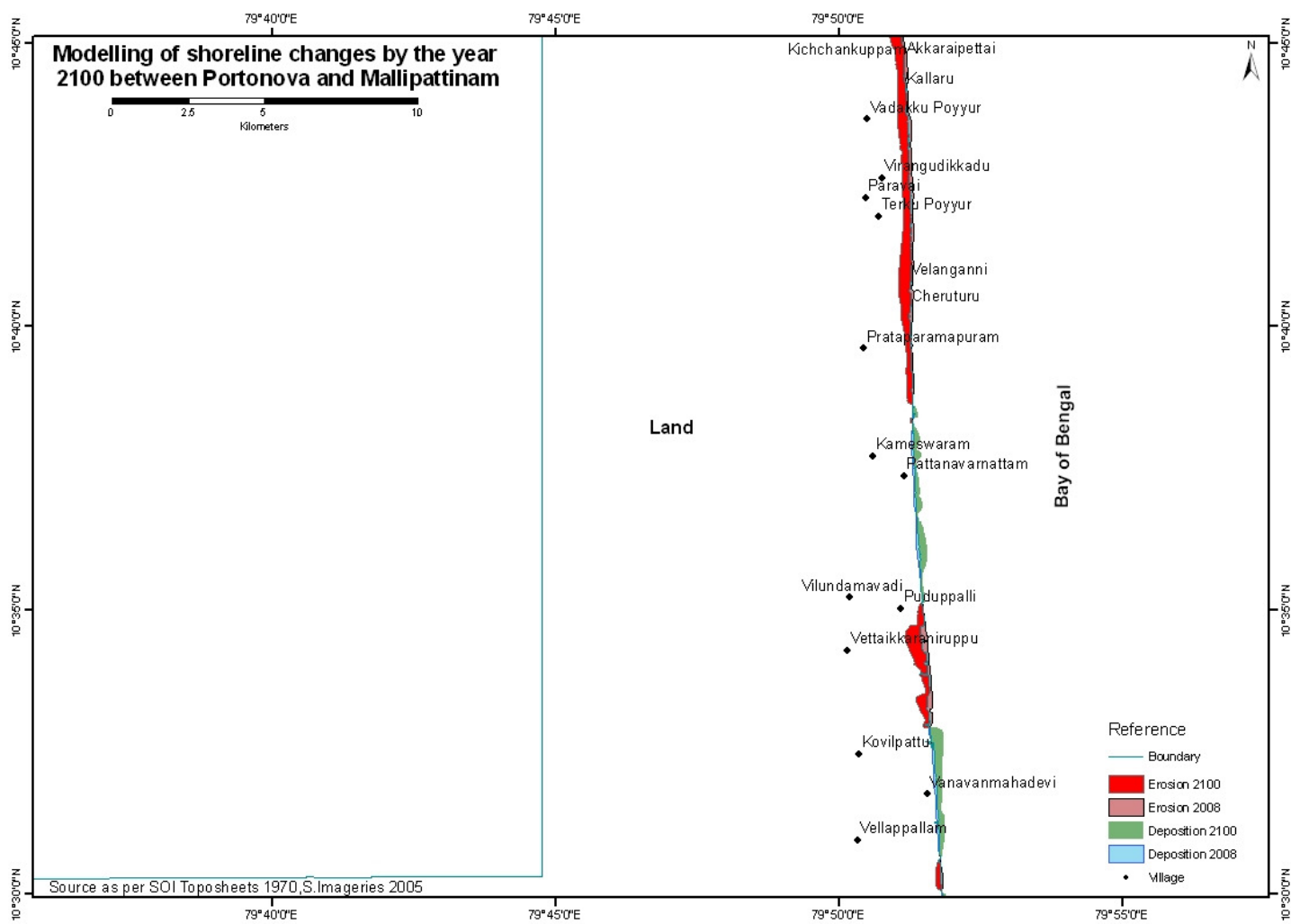

Fig - 7 Kichankuppam to Vellapallam

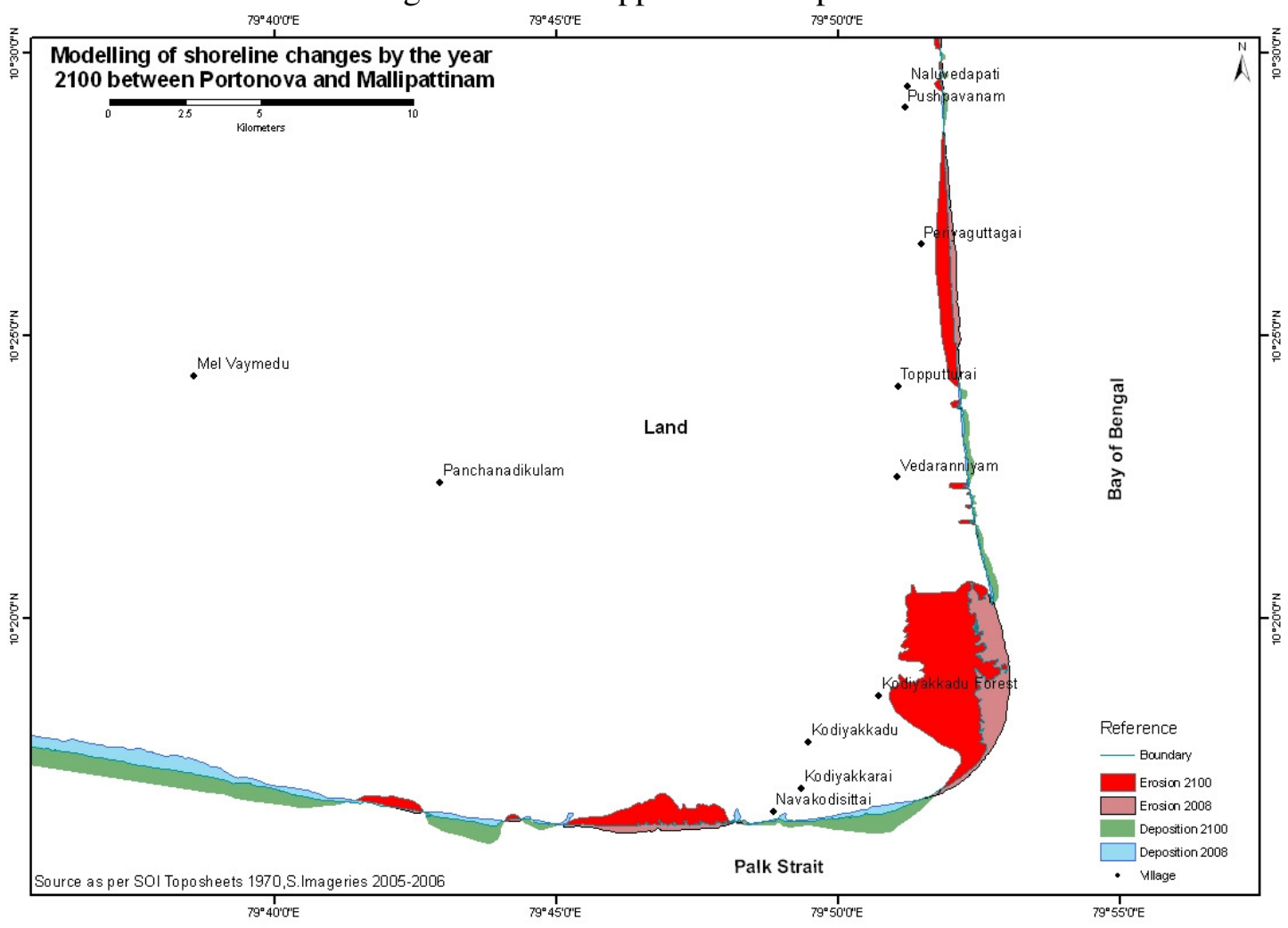

Fig - 8 Naluvedapatti to Kodiyakkarai 
International Journal of Science and Engineering Applications (IJSEA)

Volume 2 Issue 1, 2013, ISSN - 2319-7560 (online)

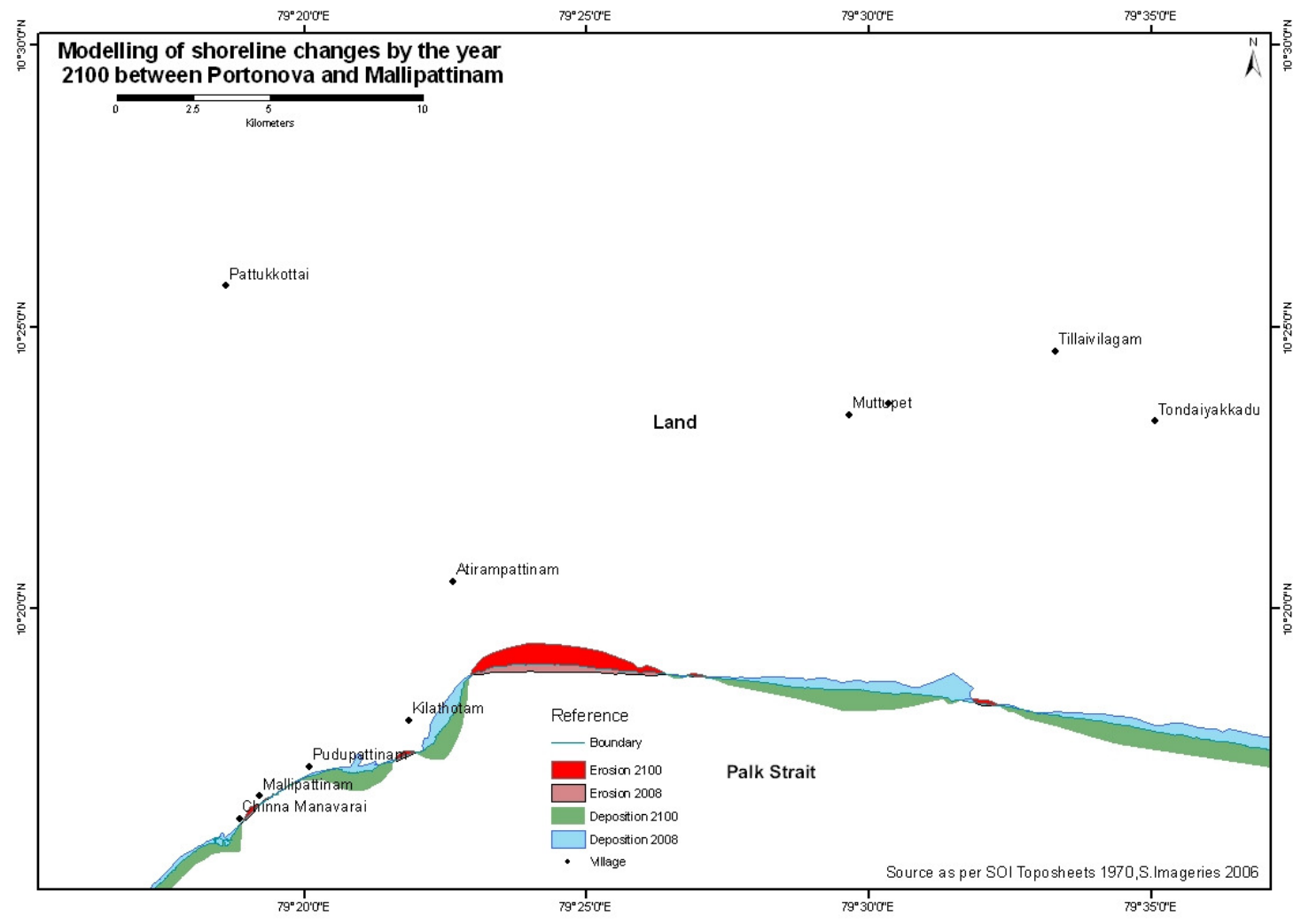

Fig 9 Thillaivilagam to Mallipattinam 